\title{
MEDICINAL PLANTS AS ALTERNATIVE TREATMENTS FOR ORAL HEALTH PROBLEMS
}

\author{
ISHFAQ KHAN, AZHAR KHAN*
}

Molecular and Immuno-parasitology Research Laboratory, Faculty of Applied Sciences and Biotechnology, Shoolini University, Solan - 173 212, Himachal Pradesh, India.*Email: mk.azhar1@gmail.com

Received: 23 January 2018, Revised and Accepted: 02 August 2018

ABSTRACT

Oral flora plays an important role in the day-to-day life for human beings and also they are important part of human digestive system. Simultaneously, besides their beneficial activities, they can be harmful to the human, and this can be evaluated as normal oral flora as opportunistic pathogens. To elevate oral sanitation, medicinal plant-based mouthwash can be used as mediator and acts as a part of efficient home care medication. In dentistry, the importance of plants has been acknowledged to cure diseases generated by several oral pathogens. Chemical drugs possess many side effects and act as a key factor responsible for developing drug-resistant microorganisms. Herbal mouthwash products have fewer side effects than chemical drugs. The worldwide requirement for substitutive prevention, treatment choices, and products for oral infections that are harmless, efficient, and low cost comes from the boost in infection occurrence. For maintaining oral sanitation, ample research has been attempted to calculate the effect of plants. The review has established to aggregate the data on herbs and plants which possess great response to the pathogens concerned with oral infections. The review will assist the researchers to discover and choose the plant to develop adequate medicine for establishing cost-effective treatment for oral hygiene.

Keywords: Oral sanitation, Antimicrobial activity, Dental biofilm.

(C) 2018 The Authors. Published by Innovare Academic Sciences Pvt Ltd. This is an open access article under the CC BY license (http://creativecommons. org/licenses/by/4. 0/) DOI: http://dx.doi.org/10.22159/ajpcr.2018.v11i9.24918

\section{INTRODUCTION}

Oral sanitation is important to universal well-being and depicts the feature of life. The connection of oral infection and microbial activities by numerous species of microorganisms as a part of microflora of the dental cavity is well recognized [1]. More than 750 bacterial species occupy the dental cavity, of which $50 \%$ are unknown and many of these species are involved in oral infection [1]. The worldwide requirement for substitutive prevention, treatment choices, and products for oral infections that are harmless, efficient, and low cost comes from the boost in infection occurrence usually in developing countries and rises in multidrug resistance by several pathogenic microorganisms to antibiotics and several drugs [2,3]. Despite advancement in the medical sciences, plants are still thought to be a vital source of different drugs in various regions around the globe [4]. Dependability and practice of herbal product have become vital because of side effects such as tooth discoloration, change in taste, and formation of resistant microbes restricted its use particularly in children. Hence, herbal mouthwash is thought to be possible biofilm (plaque) reducer and can serve as a substitute in patients with unique health requirements [5]. At least $25 \%$ of medicines are obtained from various plants, and numerous others are extracted from prototype components isolated from many species of plants [6]. Two million classical health professionals use more than 7500 species of plants which have medicinal value [7]. The medicine from plants is contributive and defensive in its approach. The World Health Organization in 2007 reported that community health expenditure specific to dental care was 5-10\%. Tooth decay and oral infection treatment are probably very expensive that people have to struggle with for lifetime [8]. Natural plant products are used even to correct numerous oral infections. In Burkina Faso, West Africa, more than 62 species of plants belong to 29 families documented to cure oral infections. It is supposed that quarter of recommended medicine contains constituents taken from the plants in industrialized countries [9]. Biofilms are gathering of bacteria which are fixed in an extracellular matrix of polymeric compounds [10]. To cure many human ailments, suffering plants were used, and knowledge about these plants is widespread in India. Ayurveda, Siddha, Unani, and Amici served the humanity for a long time. These conventional systems are alive today over a large area of the world. About $80 \%$ of people from progressing countries rely on this system to cure human diseases. Dental plaque (biofilm) is the main cause of infection. The biofilm composition changes rely on the system. The important constituents are generally bacterial cells, water, and exopolysaccharides [11]. Asian countries have used traditional medicine to correct much oral disease for more than 2000 years [12].

\section{MEDICINAL PLANTS AGAINST ORAL PATHOGENS}

\section{Azadirachta indica}

A. indica is generally known as Neem. Streptococcus sanguis subjected to pre-treatment with extract of neem showed a considerable reduction of bacterial union to saliva conditioned hydroxy apatite, which is a complex of enamel and bone. Insoluble glucan synthesis was also repressed with neem extracts, indicating that neem can reduce the attachment of Streptococcus on tooth surface [13]. Neem extract formed the maximum inhibition zone on Streptoccocus mutans at $50 \%$ concentration [14]. The effect of neem mouth rinse toward saliva levels of $S$. mutans has been studied. It was detected that the growth of $S$. mutans was repressed with or without the introduction of alcohol. The effectiveness of neem has been seen against Candida albicans and Enterococcus faecalis. Because of antioxidant and antimicrobial properties of neem plant, this makes it probable mediator substituent for root canal irrigation over sodium hypochlorite (Table 1) [15].

\section{Allium sativum}

A. sativum is generally called as garlic belonging to genus, Allium. Aqueous extract of garlic possesses antibacterial property toward a broad variety of Gram-negative, Gram-positive bacteria [16] and enterotoxin strains of Escherichia coli which are resistant to different types of chemical drugs [17] for this reason used to correct oral diseases [18]. Garlic extract remarkably inhibited S. mutans [19] derived from dental caries of human [20] because this microorganism shows resistance to antimicrobial mediators such as tetracycline, erythromycin, amoxicillin, and erythromycin. Fresh garlic extract displayed the efficient effect than the old one [21]. Adverse effects were reported such as undesirable taste, foul breath, and vomiting [22], 
Table 1: Medicinal plants used in the treatment of several diseases

\begin{tabular}{|c|c|c|c|c|c|}
\hline S. N. & Botanical name & Common name & Medicinal properties & Part used & Pictorial representation \\
\hline 1. & Azadirachta indica & Neem & $\begin{array}{l}\text { It acts as a probable } \\
\text { mediator substituent for } \\
\text { root canal irrigation [15] }\end{array}$ & Leaf & \\
\hline 2. & Allium sativum & Garlic & $\begin{array}{l}\text { Aqueous extract of garlic } \\
\text { possesses antibacterial } \\
\text { property toward a broad } \\
\text { variety of oral pathogens } \\
\text { which are resistant to } \\
\text { different types of chemical } \\
\text { drugs [16] }\end{array}$ & Bulb & \\
\hline 3. & Rosmarinus officinalis & Rosemary & $\begin{array}{l}\text { Essential oils obtained from } \\
\text { its leaf indicated antibiofilm } \\
\text { properties [26] }\end{array}$ & Leaf & \\
\hline 4. & Cinnamomum zeylanicum & Cinnamon & $\begin{array}{l}\text { Essential oils obtained from } \\
\text { it indicated antimicrobial } \\
\text { properties toward several } \\
\text { bacteria [26] }\end{array}$ & Root & \\
\hline 5. & Syzygium aromaticum & Clove & $\begin{array}{l}\text { Clove and its bud oil have } \\
\text { a strong effect against five } \\
\text { dental cavities causing } \\
\text { microorganisms such } \\
\text { as Candida albicans, } \\
\text { Staphylococcus aureus, } \\
\text { Lactobacillus acidophilus, } \\
\text { and Saccharomyces } \\
\text { cerevisiae [31] }\end{array}$ & Leaf & \\
\hline 6. & Juglans regia & Walnut & $\begin{array}{l}\text { The walnut tree has } \\
\text { antibiofilm property } \\
\text { because of various } \\
\text { phytochemical constituents } \\
\text { present in it such as } \\
\text { phenolic compounds, } \\
\text { alkaloids, tannins, ellagic } \\
\text { acid, flavonoids, and } \\
\text { steroids [35] }\end{array}$ & Stem bark & \\
\hline 7. & Mimusops elengi & Medlar & $\begin{array}{l}\text { Acetone extracts can } \\
\text { be applied to cure } \\
\text { diseases caused by oral } \\
\text { pathogens [37] }\end{array}$ & Stem bark & \\
\hline 8. & Punica granatum & Pomegranate & $\begin{array}{l}\text { The effect of extract } \\
\text { toward numerous oral } \\
\text { bacteria is because of } \\
\text { phytoconstituents such } \\
\text { as tannins and alkaloids } \\
\text { in leaves, fruits, root, and } \\
\text { stem [38] }\end{array}$ & Fruit leaves root & \\
\hline 9. & Emblica officinalis & Gooseberry & $\begin{array}{l}\text { They have a capability to } \\
\text { prevent oral infections } \\
\text { by reducing the negative } \\
\text { factors of pathogenic } \\
\text { microbes such as } \\
\text { Streptococcus mutans [50] }\end{array}$ & Fruit & \\
\hline
\end{tabular}


Table 1: (Continued)

\begin{tabular}{|c|c|c|c|c|c|}
\hline S. N. & Botanical name & Common name & Medicinal properties & Part used & Pictorial representation \\
\hline 10. & 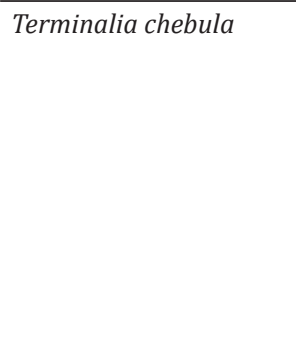 & Chebulic myrobalan & $\begin{array}{l}\text { The main phytocomponents } \\
\text { of the plant are } \\
\text { hydrolysable tannins such } \\
\text { as chebulic acid, corilagin, } \\
\text { chebulagic acid, and gallic } \\
\text { acid [51]. These acids } \\
\text { possess antimicrobial } \\
\text { activity. These acids } \\
\text { possess great effects } \\
\text { toward oral pathogens }\end{array}$ & Fruit & \\
\hline 11. & Salvadora persica & Miswak & $\begin{array}{l}\text { Over the centuries, the } \\
\text { parts of this medicinal plant } \\
\text { such as roots and stems } \\
\text { have been used as oral } \\
\text { sanitation substitutes in } \\
\text { various regions of the world } \\
\text { [56] and possess various } \\
\text { properties anti-biofilm } \\
\text { and anti-inflammation } \\
\text { property [57] }\end{array}$ & Stem & \\
\hline 12. & Sanguinaria canadensis & Bloodroot & $\begin{array}{l}\text { At a concentration of } \\
16 \mu \mathrm{g} / \mathrm{L} \text {, this plant } \\
\text { reduced } 98 \% \text { of microbial } \\
\text { population from dental } \\
\text { biofilm of human [67] }\end{array}$ & Root stem & \\
\hline 13. & Cratoxylum formosum & Mempat & $\begin{array}{l}\text { Mempat shows a great } \\
\text { effect toward Streptococcus } \\
\text { mutans and can act as } \\
\text { a good herbal product } \\
\text { against dental cavities [68] }\end{array}$ & Gum & \\
\hline 14. & Acacia catechu & Mimosa & $\begin{array}{l}\text { The heartwood extract } \\
\text { from Acacia catechu } \\
\text { possesses an efficient effect } \\
\text { against various microbes } \\
\text { which cause dental } \\
\text { cavities [69] }\end{array}$ & Stem & \\
\hline 15. & Aloe vera & Aloe & $\begin{array}{l}\text { Aloe vera has great role in } \\
\text { preventing oral diseases; it } \\
\text { contains many components } \\
\text { such as anthraquinone, } \\
\text { glycosides, aloeresins, and } \\
\text { polysaccharides [90] }\end{array}$ & Leaf & \\
\hline 16. & Curcuma longa & Turmeric & $\begin{array}{l}\text { The oil from turmeric } \\
\text { possesses oncopreventive } \\
\text { activity, cures numerous } \\
\text { oral diseases, and reduces } \\
\text { gum inflammation [81] }\end{array}$ & Tubers & \\
\hline 17. & $\begin{array}{l}\text { Melaleuca } \\
\text { alternifolia }\end{array}$ & Paperbark & $\begin{array}{l}\text { Paperbark tree produces } \\
\text { important oil known as tea } \\
\text { tree oil. In } 1930 \text { 's, tea tree } \\
\text { oil was already identified } \\
\text { as possessing importance } \\
\text { in oral sanitation [73], } \\
\text { and tea tree oil contains } \\
\text { almost } 100 \text { constituents } \\
\text { and has revealed immense } \\
\text { range of anti-swelling } \\
\text { and antibacterial } \\
\text { properties [74] }\end{array}$ & Leaf & . \\
\hline
\end{tabular}


but the effectiveness of garlic extract was greater than chlorhexidine toward the particular bacteria and therefore can be considered as an efficient mouth rinse. Mouth rinse having $10 \%$ of garlic in a quarter Ringer solution showed an immense decrease of oral pathogenic bacteria (Table 1) [23].

\section{Piper betle}

$P$. betle is a vine leaf included in a family of Piperaceae. Aqueous extract from leaves in crude form showed decreased effect on the growth, attachment capability, and glucosyltransferase action against the $S$. mutans [24]. Nalina et al. also reported the effect of P. betle leaf extract on the ultrastructure of S. mutans and she concluded that this might be due to the presence of fatty acids and hydroxy fatty acid ester components present in the leaves extract.. Relating to dental biofilm, the repressed growth of bacteria can hinder the biofilm on the surface of the tooth. Consequently, the introduction of this extract in mouthwash can control oral plaque (Table 1).

\section{Rosemary and cinnamon}

Rosemary officinalis is a woody herb with sweet smelling indigenous to Mediterranean area. Rosemary showed great effects against $S$. mutans [24]. Its antimicrobial activity was greater than chlorhexidine mouthwash [25]. More studies are recommended for making of herbal mouth rinse. Essential oils obtained from it indicated antimicrobial properties toward several bacteria [26]. Higher antimicrobial property was seen against the strains Arcobacter butzleri using extracts of cinnamon, sage, barberry, chamomile, and rosemary [15]. Aqueous extract from cinnamon acquires great antimicrobial property toward Pseudomonas aeruginosa [27]. When a mixture of Chinese chive, corni fructus, and cinnamon extract was formed, it possessed antimicrobial property toward E. coli. These extracts showed high stability toward $\mathrm{pH}$ and heat [28]. Chamomile reduced the number of Helicobacter pylori (Table 1) [29]. The extracts of chamomile have reasonable antimicrobial properties [30].

\section{Syzygium aromaticum}

$S$. aromaticum generally known as clove is indigenous to Indonesia which is used as a spice throughout the world. The clove oil is commonly used to cure toothache. Without any dilution, the clove oil from clove is applied to the tooth cavity using cotton plug. Methanolic extracts in crude form possessed great effect toward Gram-negative pathogen which causes gum diseases (Table 1) [31]. Kaempferol and myricetin represented an increased antimicrobial effect toward oral pathogens which can cause tooth decay. Clove and its bud oil have a strong effect against five dental cavity causing microorganisms such as C. albicans, Staphylococcus aureus, Lactobacillus acidophilus, and Saccharomyces cerevisiae. The authors recommend that clove and its oil can be used as antimicrobial mediators.

\section{Juglans regia}

The plant commonly known as walnut is a big deciduous tree which is found in Iran, Baluchistan, Himalayan regions of India, Armenia and several temperate regions [32]. Almost all the parts of this large tree like stem, bark, root, seeds, leaves and oil are used to cure several diseases [33]. Efficiency of acetone and aqueous extracts of walnut has been determined by testing these extracts on saliva samples obtained from patients who have problems related to dental cavities [34]. Using disc diffusion procedure, antimicrobial analysis was done, and the acetone extracts were depicted to be more efficient as antipathogenic medicine. The walnut tree has antimicrobial property because of various phytochemical constituents present in it such as phenolic compounds, alkaloids, tannins, ellagic acid, flavonoids, and steroids (Table 1) [35].

\section{Myristica fragrans}

M. fragrans evergreen tree mainly found in Moluccas Islands of Indonesia. The ethanolic extracts possessed excellent antimicrobial activities toward Porphyromonas and Fusobacterium (Table 1) [36].

\section{Mimusops elengi}

This is an average-sized tree which is evergreen and concentrated to Tropical forests in Asia and Australia. In general, it is called as Spanish
Cherry, Maulsari in Hindi, Bokul in Assamese, and Bakul in Bengali. The extract from the bark was examined to check its effect against the oral microbes taken from the children 6-12 years of age. The outcome verified the effect of this plant and showed that acetone extracts can be applied to cure diseases caused by oral pathogens (Table 1) [37].

\section{Punica granatum}

P. granatum is indigenous to Asia. The effect of extract toward numerous oral bacteria is because of phytoconstituents such as tannins and alkaloids in leaves, fruits, root, and stem [38]. There is growing curiosity in using tannins as antimicrobial mediators to eliminate oral pathogens responsible for many oral diseases [39]. This plant has been detected for efficiency [40-42]. The extracts from plant usually ethanolic extract, aqueous extract, methanolic extract, and acetone extract showed a high effect in several studies on numerous bacteria [38,43-45]. In another study, the gel obtained from this plant showed the positive effect by hindering the biofilm formation [41]. A study of hydroalcoholic extracts of fruits of this plant showed an efficient antimicrobial property toward dental plaque pathogens [40]. Due to its anti-inflammatory properties, it is used to correct many throat infections, cough, and fever [46]. The most important constituents present in pomegranate are flavonoids, anthocyanidins, ellagic acid, ellagitannins, flavones, estrogenic flavonols, and punicic acid. Juice, seed oil, and peel extract of pomegranate possess reduced effect on prostate cancer [47]. A study reported that extract from pomegranate was more efficient to decrease the biofilm than chemical drugs when three or more organisms were involved in biofilm formation (Table 1) [48].

\section{Emblica officinalis}

In general, it is known by different names such as amala, Indian gooseberry, oval, and amlaki. The various phytoconstituents such as phenols, flavonoids, tannins, polyphenols, ellagic acid, and gallic acid are present in this plant [49]. They have a capability to prevent oral infections by reducing the negative factors of pathogenic microbes such as S. mutans and Lactobacillus, (Table 1) [50]. The effect of amala was greater than chlorhexidine and can serve as an effective mouth rinse.

\section{Terminalia chebula}

The plant also called as kadukka. The main phytocomponents of the plant are hydrolysable tannins such as chebulic acid, corilagin, chebulagic acid, and gallic acid [51]. These acids possess antimicrobial activity. These acids possess great effects toward oral pathogens [52]. It has been depicted that kadukka can be an efficient anticavity mouth rinse, (Table 1) [53]. The aqueous extract greatly reduced the growth and sucrose-induced attachment of $S$. mutans $[54,55]$. The aqueous extracts were more efficient than chlorhexidine.

\section{Salvadora persica}

This tree also called Miswak tree. Over the centuries, the parts of this medicinal plant such as roots, and stems have been used as oral sanitation substitutes in various regions of the world [56] and possess various properties anti-biofilm and anti-inflammation property [57]. Furthermore, low dental cavities have been seen among people who frequently use miswak [58]. In a study, alcoholic and aqueous extracts of this plant possessed antimicrobial properties toward various types of pathogenic microbes such as $S$. mutans and Emblica corrodens [59,60].

According to a study, persica mouth rinse decreases the growth of various oral pathogenic bacteria and reduced the occurrence of oral infection and gum inflammation [58,61]. In several studies, low-tomedium antimicrobial effect was reported for the ethanolic and aqueous extracts of miswak $[62,63]$ and discovered that miswak parts fixed in an agar medium possessed very efficient effect than the aqueous extract of miswak [63]. Several researchers depicted from a study of children that the frequent use of miswak for cleaning teeth reduced the gum inflammation [64].

In vitro studies depicted that numerous bacteria as Streptococcus are particularly susceptible to antimicrobial effects possessed by miswak [62]. In a study, it was depicted that the formation of dental 
cavities in control group was 9-30 times greater than the case group [65]. Various clinical studies depicted that daily use of miswak decreases the biofilm on the surface of the teeth. The gum inflammation was greatly reduced than pre-treatment group [61]. For reducing biofilm formation and swelling of gums, it was found that the use of miswak was efficient substitute for controlling oral diseases, (Table 1) [66].

S. mutans were very sensitive to antimicrobial activity possessed by miswak than Lactobacilli [58]. Mouth rinse with persica extracts seems to have no side effects. In another study, it has shown that mouth rinse with persica considerably decreases the biofilm on teeth surface and inflammation of gums without any side effects. This also controls the biofilm on teeth surfaces and cavities, and the miswak extracts can be introduced into mouth washes and tooth pastes [60].

\section{Sanguinaria canadensis}

S. canadensis generally called as bloodroot is a flowering perennial plant found in North America and Canada. Various studies were performed to know its effects on microbes. A mouthwash and toothpaste with extract of $S$. canadensis given for at least 6 months during the medical treatment decreased the dental biofilm by $57 \%$ and inflammation of gum by $60 \%$ than the control group where the effect was $27 \%$ and $21 \%$, respectively. At a concentration of $16 \mu \mathrm{g} / \mathrm{l}$, this plant reduced $98 \%$ of microbial population from dental biofilm of human and combining effect of extract from $S$. canadensis and zinc suppressed the number of different Streptococci found in the mouth, (Table 1) [67].

\section{Cratoxylum formosum}

The plant is generally called as Mempat. The gum obtained from Mempat is a natural mediator that has been used broadly by tribal people in Thailand to reduce dental cavities. A gum obtained from Mempat showed a great effect toward $S$. mutans and can act as a good herbal product against dental cavities (Table 1) [68].

\section{Acacia catechu}

A. catechu belonging to family Fabaceae and subfamily Mimosoideae is broadly used Ayurveda for the treatment of many diseases. The heartwood extract from $A$. catechu possesses an efficient effect against various microbes which cause dental cavities [69]. A research on this plant concluded that about $80-95 \%$ of reduction was seen in biofilm until 15 days [70]. Excellent results were shown with petroleum ether extract toward $P$. aeruginosa followed by aqueous extract against Bacillus subtilis, and chloroform extract showed effect toward $S$. aureus [71]. Effective and broadest antimicrobial effect was found with ethanolic extract (Table 1) [72]. Hence, acacia proved to be a great antimicrobial mediator toward oral infections which are caused mainly by $S$. mutans.

\section{Tea tree oil}

Paperbark tree produces important oil known as tea tree oil. In 1930 's, tea tree oil was already identified as possessing importance in oral sanitation [73]. Tea tree oil contains almost 100 constituents and has revealed an immense range of anti-swelling and antibacterial properties [74]. A broad variety of oral microorganisms is sensitive to this oil [74]. Toothpaste such as Melafresh T-96 made by an Australian company added this oil into it with a concentration of $0.2 \%$. It still possesses great effect against the numerous bacteria even after the loss of activity during manufacturing process (Table 1) [75]. Effect toward $S$. mutans was showed by this oil [76]. The oil can also act as root canal irrigant but not efficient than EDTA [77], and various evidences indicated that this oil can be a substitute to chlorhexidine.

\section{Turmeric}

Turmeric requires a temperature of $20-30^{\circ} \mathrm{C}$. Turmeric consists of tubers whose length is 2-3 inches and having a diameter of one inch. Due to its antibacterial properties, it is used to eliminate dental diseases $[78,79]$. Phytoconstituents in turmeric are diferuloylmethane and many volatile oils including atlantone. In Ayurveda, it is extensively used a for long time having no side effects and has different medicinal properties which include analgesic, anti-inflammatory, antioxidant, antiseptic, and anticarcinogenic activity [80]. In another study, it was detected that curcumin can cure different pre-cancerous situations such as oral submucous fibrosis, lichen planus, and leukoplakia. The oil from turmeric possessed oncopreventive activity [81] and cure numerous oral diseases. Application of roasted, ground turmeric reduces the pain and swelling [80]. Another study concluded that turmeric solution can greatly reduce the gum inflammation than chlorhexidine (Table 1) [82].

\section{Aloe vera}

A. vera also known $A$. vera barbadensis miller is perennial, xerophytic green color plant. It grows abundantly in dry areas of Asia, Europe, and America. A. vera is a good wound healer [83]. Components in A. vera are salicylic acid, urea, cinnamic acid, and phenols, and all these components have reducing effect on bacteria, viruses, and fungi. A. vera was found to be vital for preventing cancer, mucositis, aphthous stomatitis, and radiation dermatitis [84-87]. It is an anti-inflammatory mediator which has inhibitory effect on cyclooxygenase pathway and decreases prostaglandin E2 formation from arachidonic acid. A. vera has great antibacterial, antifungal, antiviral, and anticarcinogenic properties [88]. In another study, its leaf pulp extract reduced the blood sugar level, and as an antioxidant agent, it eliminates the free radicals(Table 1) [89]. A. vera has a great role to cure oral disease, and it contains many components such as anthraquinone glycosides, aloeresins, galactomannans, and polysaccharides [90]. Phenolic antioxidative substances were recently extracted from it and recognized as derivatives of oleoresins [91]. Many medicinal properties, no side effects, and less cost make it an important substituent to control biofilm on the surface of teeth and hence reduce gum inflammation and other oral diseases [92]. Acetylated mannans from it play a key role to increase immune system functioning. The gel obtained from it possesses anticancer, antidiabetic, and antibiotic properties [90]. 30 days of mouthwash with A. vera reduced the biofilm on the teeth surface(Table 1) [93].

\section{HERBAL ORAL RINSES AND HERBAL MIXTURE}

Different mouth rinses are commercially used. Herbal oral rinses which contain Yavani satva, Bibhitaka (Terminalia bellirica), and Peppermint satva are effective toward gingivitis. As compared to chlorhexidine, the usage of herbal oral rinses such as neem [94], turmeric [95], and triphala [96] showed a higher decrease in biofilm, inflammation of gums, and gum bleeding. The herbal mixture mainly in crude form can be introduced as a component for toothpaste [97]. Mixture of various herbal components helps in maintaining the good oral hygiene as a result reduces dental biofilm and decreases inflammation of gums [98].

\section{CONCLUSION}

Herbal antimicrobial mediators may inhibit the biofilm and oral infections. Therefore, the antimicrobial mediators need to have the capability of eliminating the oral microbes and preventing many oral infections. Medicinal plants and important oils such as paperbark oil are becoming successful as substituent's of chemical drugs for their effectiveness in preventing many oral diseases. It is supposed that a quarter of recommended medicine possesses constituents taken from plants in industrialized countries [9]. The challenge is to discover medicinal plants which have capability eliminate oral diseases. Therefore, the plant should possess antimicrobial activities without affecting the epithelial cells of human.

\section{ACKNOWLEDGMENT}

The authors sincerely thank Shoolini University, Solan, H.P, for contributing to this study.

\section{CONTRIBUTION OF AUTHORS}

Ishfaq Khan: Compiled the literature sources, data analysis, and interpretation and wrote the manuscript. Azhar Khan: Helped in data 
interpretation, conceptualization of work, and its realization and manuscript evaluation

\section{CONFLICTS OF INTEREST}

The authors declared that they have no conflicts of interest.

\section{REFERENCES}

1. Jenkinson HF, Lamont RJ. Oral microbial communities in sickness and in health. Trends Microbiol 2005;13:589-95.

2. Tichy J, Novak J. Extraction, assay, and analysis of antimicrobials from plants with activity against dental pathogens (Streptococcus sp.) J Altern Complement Med 1998;4:39-45.

3. Badria FA, Zidan OA. Natural products for dental caries prevention. J Med Food 2004;7:381-4.

4. Yadav M, Chatterji S, Gupta SK, Watal G. Preliminary phytochemical screening of six medicinal plants used in traditional medicine. Int $\mathrm{J}$ Pharm Pharm Sci 2014;6:539-42.

5. Subramaniam P, Gupta T. Efficacy of a herbal mouthrinse on oral microbial load in down syndrome children. Int $\mathrm{J}$ Herbal Med 2013;1:50-4

6. Kala CP, Dhyani PP, Sajwan BS. Developing the medicinal plants sector in Northern India: Challenges and opportunities. J Ethnobiol Ethnomed 2006;2:32.

7. Kanwar P, Sharma N, Rekha A. Medicinal plants use in traditional healthcare systems prevalent in Western Himalayas. Indian J Tradit Knowl 2006;5:300-9.

8. Loesche WJ. Role of Streptococcus mutans in human dental decay. Microbiol Rev 1986;50:353-80.

9. Runyoro DK, Ngassapa OD, Matee MI, Joseph CC, Moshi MJ. Medicinal plants used by Tanzanian traditional healers in the management of Candida infections. J Ethnopharmacol 2006;106:158-65.

10. Branda SS, Vik S, Friedman L, Kolter R. Biofilms: The matrix revisited. Trends Microbiol 2005;13:20-6.

11. Sutherland I. Biofilm exopolysaccharides: A strong and sticky framework. Microbiology 2001;147:3-9.

12. Zhu L, Petersen PE, Wang HY, Bian JY, Zhang BX. Oral health knowledge, attitudes and behaviour of adults in China. Int Dent $\mathrm{J}$ 2005;55:231-41.

13. Wolinsky LE, Mania S, Nachnani S, Ling S. The inhibiting effect of aqueous Azadirachta indica (Neem) extract upon bacterial properties influencing in vitro plaque formation. J Dent Res 1996;75:816-22.

14. Prashant GM, Chandu GN, Murulikrishna KS, Shafiulla MD. The effect of mango and neem extract on four organisms causing dental caries: Streptococcus mutans, Streptococcus salivavius, Streptococcus mitis, and Streptococcus sanguis: An in vitro study. Indian J Dent Res 2007; $18: 148-51$

15. Vanka A, Tandon S, Rao SR, Udupa N, Ramkumar P. The effect of indigenous Neem Azadirachta indica [correction of (Adirachta indica)] mouth wash on Streptococcus mutans and lactobacilli growth. Indian J Dent Res 2001;12:133-44

16. Amin M, Kazemi M, Neda R. In vitro comparison of the effects of garlic juice and chlorhexidine mouthwash on oral pathogen. Jundishapur $\mathrm{J}$ Microbiol 2012;1:398-400.

17. Ankri S, Mirelman D. Antimicrobial properties of allicin from garlic. Microbes Infect 1999;1:125-9

18. Bakri IM, Douglas CW. Inhibitory effect of garlic extract on oral bacteria. Arch Oral Biol 2005;50:645-51.

19. Xavier TF, Vijyalakshmi P. Screening of antibiotic resistant inhibitors from Indian traditional medicinal plants against Streptococcus mutans. J Plant Sci 2007;2:370-3.

20. Fani MM, Kohanteb J, Dayaghi M. Inhibitory activity of garlic (Allium sativum) extract on multidrug-resistant Streptococcus mutans. J Indian Soc Pedod Prev Dent 2007;25:164-8.

21. Sasaki J, Kita T, Ishita K, Uchisawa H, Matsue H. Antibacterial activity of garlic powder against Escherichia coli O-157. J Nutr Sci Vitaminol (Tokyo) 1999;45:785-90.

22. Groppo FC, Ramacciato JC, Motta RH, Ferraresi PM, Sartoratto A. Antimicrobial activity of garlic against oral streptococci. Int J Dent Hyg 2007;5:109-15.

23. Elnima EI, Ahmed SA, Mekkawi AG, Mossa JS. The antimicrobial activity of garlic and onion extracts. Pharmazie 1983;38:747-8.

24. Nalina T, Rahim ZH. The crude aqueous extract of Piper betle and its antibacterial effect towards Streptococcus mutans. Am J Biochem Biotechnol 2007;3:10-5

25. Dalirsani Z, Aghazadeh M, Adibpour M, Amirchaghmaghi M,
Pakfetrat A, Mozaffari PM, et al. In vitro comparison of the antimicrobial activity of ten herbal extracts against Streptococcus mutans with chlorhexidine. J Appl Sci 2011;11:878-82.

26. Bozin B, Mimica-Dukic N, Samojlik I, Jovin E. Antimicrobial and antioxidant properties of rosemary and sage (Rosmarinus officinalis L. and Salvia officinalis L. Lamiaceae) essential oils. J Agric Food Chem 2007:55:7879-85.

27. Ibrahim YK, Ogunmodede MS. Growth and survival of Pseudomonas aeruginosa in some aromatic waters. Pharm Acta Helv 1991;66:286-8.

28. Mau J, Chen C, Hsieh P. Antimicrobial effect of extracts from Chinese chive, cinnamon, and corni fructus. J Agric Food Chem 2001;49:183-8.

29. Weseler A, Geiss HK, Saller R, Reichling J. A novel colorimetric broth microdilution method to determine the minimum inhibitory concentration (MIC) of antibiotics and essential oils against Helicobacter pylori. Pharmazie 2005;60:498-502.

30. McKay DL, Blumberg JB. A review of the bioactivity and potential health benefits of chamomile tea (Matricaria recutita L.). Phytother Res 2006;20:519-30.

31. Cai L, Wu CD. Compounds from Syzygium aromaticum possessing growth inhibitory activity against oral pathogens. J Nat Prod 1996;59:987-90.

32. Chopra RN, Nayar SL, Chopra RC, Asolkar LV, Kakkar KK, Chakre OJ, et al. Glossary of Indian Medicinal Plants (Including the Supplement). New Delhi: Council of Scientific \& Industrial Research; 1956-92. p. 11.

33. Duke JA. Handbook of Energy Crops. Lafayette: Purdue University, Center for New Crops \& Plants Products; 1983. p. 26.

34. Deshpande RR, Kale AA, Ruikar AD, Panvalkar PS, Kulkarni AA, Deshpande NR, et al. Antimicrobial activity of different extracts of Juglans regia L. against oral microflora. Int J Pharm Pharm Sci 2011;3:200-1

35. Bandow JE, Brötz H, Leichert LI, Labischinski H, Hecker M. Proteomic approach to understanding antibiotic action. Antimicrob Agents Chemother 2003;47:948-55.

36. Jaiswal P, Kumar P, Singh VK, Singh DK. Biological effects of Myristica fragrans. Ann Rev Biomed Sci 2009;11:21-9.

37. Deshpande RR, Ruikar A, Panvalkar PS, Kulkarni AA, Khatiwora E, Adasul V, et al. Comparative evaluation of different concentrations of Mimusops elengi (L) extract as an antimicrobial agent against salivary micro flora. J Biomed Sci Res 2010;2:151-4.

38. Silva M, Higino J, Pereira J, Siqueira-Junior J, Pereira M. Antibiotic activity of the extract of Punica granatum Linn over bovine strains of Staphylococcus aureus. Braz J Pharmacogn 2008;18:209-12.

39. Scalbert A. Antimicrobial properties of tannins. Chemistry 1991;30:3875-83.

40. Menezes SM, Cordeiro LN, Viana GS. Punica granatum (pomegranate) extract is active against dental plaque. J Herb Pharmacother 2006;6:79 92.

41. Pereira JV, Pereira MS, Sampaio FC, Sampaio MC, Lves M, Rajo CR, et al. In vitro antibacterial and anti adherence effect of Punica granatum Linn extract upon dental biofilm microorganisms. Braz J Pharmacogn 2006;16:88-93.

42. Vasconcelos LC, Sampaio FC, Sampaio MC, Pereira Mdo S, Higino JS, Peixoto MH, et al. Minimum inhibitory concentration of adherence of Punica granatum linn (pomegranate) gel against S. mutans, S. mitis and C. albicans. Braz Dent J 2006;17:223-7.

43. Haghighati F, Jaafari S, BeytElahi JM. Comparison of antimicrobial effects of ten herbal extracts with chlorhexidine on three different oral pathogens; an in vitro study. HAKIM 2003;6:71-6.

44. Machado Thelma de B, Leal Ivana CR, Amaral AC, Santos KR, Silva MG, Kuster RM. Antimicrobial ellagitannin of Punica granatum fruits. J Braz Chem Soc 2002;13:606-10.

45. Reddy MK, Gupta SK, Jacob MR, Khan SI, Ferreira D. Antioxidant, antimalarial and antimicrobial activities of tannin-rich fractions, ellagitannins and phenolic acids from Punica granatum L. Planta Med 2007;73:461-7.

46. Salgado AD, Maia JL, Pereira SL, de Lemos TL, Mota OM. Antiplaque and antigingivitis effects of a gel containing Punica granatum linn extract: A double-blind clinical study in humans. J Appl Oral Sci 2006;14:162-6.

47. Jurenka JS. Therapeutic applications of pomegranate (Punica granatum L.): A review. Altern Med Rev 2008;13:128-44.

48. Vasconcelos LC, Sampaio MC, Sampaio FC, Higino JS. Use of Punica granatum as an antifungal agent against candidosis associated with denture stomatitis. Mycoses 2003;46:192-6.

49. Nair R, Chanda SV. Antibacterial activities of some medicinal plants of the Western Region of India. Turk J Biol 2007;31:231-6.

50. Hasan S, Danishuddin M, Adil M, Singh K, Verma PK, Khan AU, et al. 
Efficacy of E. officinalis on the cariogenic properties of Streptococcus mutans: A novel and alternative approach to suppress quorum-sensing mechanism. PLoS One 2012;7:e40319.

51. Han Q, Song J, Qiao C, Wong L, Xu H. Preparative isolation of hydrolysable tannins chebulagic acid and chebulinic acid from Terminalia chebula by high-speed counter-current chromatography. J Sep Sci 2006;29:1653-7.

52. Aneja KR, Joshi R. Evaluation of antimicrobial properties of fruit extracts of Terminalia chebula against dental caries pathogens. Jundishapur J Microbiol 2009;2:105-11.

53. Carounanidy U, Satyanarayanan R, Velmurugan A. Use of an aqueous extract of Terminalia chebula as an anticaries agent: A clinical study. Indian J Dent Res 2007;18:152-6.

54. Jagtap AG, Karkera SG. Potential of the aqueous extract of Terminalia chebula as an anticaries agent. J Ethnopharmacol 1999;68:299-306.

55. Nayak SS, Kumar BR, Ankola AV, Hebbal M. The efficacy of Terminalia chebula rinse on Streptococcus mutans count in saliva and its effect on salivary pH. Oral Health Prev Dent 2010;8:55-8.

56. Al-Sabawi NA, Al-Sheikh Abdal AK, Taha MY. The antimicrobial activity of Salvadora persica solution (Miswak-Siwak) as root canal irrigant (A comparative study). J Pure Appl Sci 2007;4:69-91.

57. Darout IA, Christy AA, Skaug N, Egeberg PK. Identification and quantification of some potentially antimicrobial anionic components in Miswak extract. Indian J Pharmacol 2000;32:11-4.

58. Almas K, Al-Zeid Z. The immediate antimicrobial effect of a toothbrush and miswak on cariogenic bacteria: A clinical study. J Contemp Dent Pract 2004;5:105-14

59. Abdeirahman HF, Phil M, Skaug N, Francis GW. In vitro antimicrobial effects of crude Miswak extracts on oral pathogens. Dent J 2002;14:2632.

60. Poureslami HR, Makarem A, Mojab F. Paraclinical effects of Miswak extract on dentalplaque. Dent Res J 2007;4:106-10.

61. Khalessi AM, Pack AR, Thomson WM, Tompkins GR. An in vivo study of the plaque control efficacy of persica: A commercially available herbal mouthwash containing extracts of Salvadora persica. Int Dent J 2004:54:279-83.

62. Al Lafi T, Ababneh $\mathrm{H}$. The effect of the extract of the miswak (chewing sticks) used in Jordan and the Middle East on oral bacteria. Int Dent J 1995:45:218-22.

63. Sofrata A, Lingström P, Baljoon M, Gustafsson A. The effect of miswak extract on plaque $\mathrm{pH}$. An in vivo study. Caries Res 2007;41:451-4.

64. Gazi MI, Davies TJ, al-Bagieh N, Cox SW. The immediate- and medium-term effects of meswak on the composition of mixed saliva. J Clin Periodontol 1992;19:113-7.

65. Aldini EZ, Ardakani F. Efficacy of miswak (Salvadora persica) in prevention of dental caries. Shahid Sadoughi Univ Med Sci Health Ser 2007; $14: 24-31$

66. al-Otaibi M. The Miswak (chewing stick) and oral health. Studies on oral hygiene practices of urban Saudi Arabians. Swed Dent J Suppl 2004;167:2-75.

67. Eley BM. Antibacterial agents in the control of supragingival plaque - a review. Br Dent J 1999;186:286-96.

68. Suddhasthira T, Thaweboon S, Dendoung N, Thaweboon B, Dechkunakorn S. Antimicrobial activity of Cratoxylum formosum on Streptococcus mutans. Southeast Asian J Trop Med Public Health 2006;37:1156-9.

69. Geetha RV, Roy A, Lakshmi T. In vitro evaluation of Anti bacterial activity of heartwood extract of Acacia catechu on oral microbes. Int $\mathbf{J}$ Curr Res Rev 2011;3:4-9.

70. Kumar P, Ansari SH, Ali J. Herbal remedies for the treatment of periodontal disease - a patent review. Recent Pat Drug Deliv Formul 2009;3:221-8

71. Patel J, Kumar V, Bhatt S. Antimicrobial screening and phytochemical analysis of the resin part of Acacia catechu. Pharm Biol J 2009;47:34-7.

72. Gulzar A, Manjul PS, Anita S, Upendra K, Yatendra K. Preliminary phytochemical and antimicrobial screening of leaves extract of Acacia catechu Willd. J Pharm Res 2010;3:2583-4.

73. Carson CF, Riley TV. Antimicrobial activity of the essential oil Melaleuca alternifolia. Lett Appl Microbiol 1993;16;49:55.

74. Hammer KA, Dry L, Johnson M, Michalak EM, Carson CF, Riley TV, et al. Susceptibility of oral bacteria to Melaleuca alternifolia (tea tree) oil in vitro. Oral Microbiol Immunol 2003;18:389-92.

75. Bolel S. Tea tree oil keeps mouths clean. South Afr Pharm Cosmet Rev 2009;36:34
76. Groppo FC, Ramacciato JC, Simões RP, Flório FM, Sartoratto A. Antimicrobial activity of garlic, tea tree oil, and chlorhexidine against oral microorganisms. Int Dent J 2002;52:433-7.

77. Sadr Lahijani MS, Raoof Kateb HR, Heady R, Yazdani D. The effect of German chamomile (Marticaria recutita L.) extract and tea tree (Melaleuca alternifolia L.) oil used as irrigants on removal of smear layer: A scanning electron microscopy study. Int Endod J 2006;39:190 5.

78. Ramirez S, Bosca A, Soler A, Gutierrez MA, Antioxidant curcuma extracts decrease the blood lipid peroxide levels of human subjects. Age 1995;92:167-9

79. Kiso Y, Suzuki Y, Watanabe N, Oshima Y, Hikino H. Antihepatotoxic principles of curcuma longa rhizomes. Planta Med 1983;49:185-7.

80. Çıkrıkçı S, Mozioglu E, Yılmaz H. Biological activity of curcuminoids isolated from Curcuma longa. Rec Nat Prod 2008;2:24-94.

81. Deepa DA, Anita B, Sreelatha KT. Comparative study of the efficacy of curcumin and turmeric oil as chemo protective agents in oral submucous fibrosis: A clinical and histopathological evaluation. JIAOMR 2010;22:88-92

82. Suhag A, Dixit J, Dhan P. Role of curcumin as a subgingival irrigant: A pilot study. PERIO Periodontal Pract Today 2007;2:115-21.

83. Heggers JP, Kucukcelebi A, Listengarten D, Stabenau J, Ko F, Broemeling LD, et al. Beneficial effect of aloe on wound healing in an excisional wound model. J Altern Complement Med 1996;2:271-7.

84. Furukawa F, Nishikawa A, Chihara T, Shimpo K, Beppu H, Kuzuya H, et al. Chemopreventive effects of aloe arborescens on N-nitrosobis(2oxopropyl)amine-induced pancreatic carcinogenesis in hamsters. Cancer Lett 2002;178:117-22.

85. Fenig E, Nordenberg J, Beery E, Sulkes J, Wasserman L. Combined effect of aloe-emodin and chemotherapeutic agents on the proliferation of an adherent variant cell line of merkel cell carcinoma. Oncol Rep 2004;11:213-7.

86. Garnick JJ, Singh B, Winkley G. Effectiveness of a medicament containing silicon dioxide, aloe, and allantoin on aphthous stomatitis. Oral Surg Oral Med Oral Pathol Oral Radiol Endod 1998;86:550-6.

87. Su CK, Mehta V, Ravikumar L, Shah R, Pinto H, Halpern J, et al. Phase II double-blind randomized study comparing oral Aloe vera versus placebo to prevent radiation-related mucositis in patients with headand-neck neoplasms. Int J Radiat Oncol Biol Phys 2004;60:171-7.

88. West DP, Zhu YF. Evaluation of Aloe vera gel gloves in the treatment of dry skin associated with occupational exposure. Am J Infect Control 2003;31:40-2.

89. Okyar A, Can A, Akev N, Baktir G, Sütlüpinar N. Effect of Aloe vera leaves on blood glucose level in type I and type II diabetic rat models. Phytother Res 2001;15:157-61.

90. Reynolds T, Dweck AC. Aloe vera leaf gel: A review update. J Ethnopharmacol 1999;68:3-7.

91. Yagi A, Kabash A, Okamura N, Haraguchi H, Moustafa SM, Khalifa TI, et al. Antioxidant, free radical scavenging and anti-inflammatory effects of aloesin derivatives in Aloe vera. Planta Med 2002;68:957-60.

92. Grindlay D, Reynolds T. The Aloe vera phenomenon: A review of the properties and modern uses of the leaf parenchyma gel. J Ethnopharmacol 1986;16:117-51.

93. Villalobos OJ, Salazar CR, Sanchez GR. Effect of a mouth wash made of Aloe vera on plaque and gingival inflammation. Acta Odontol Venez 2001;39:16-24.

94. Chatterjee A, Saluja M, Singh N, Kandwal A. To evaluate the antigingivitis and antipalque effect of an Azadirachta indica (neem) mouthrinse on plaque induced gingivitis: A double-blind, randomized, controlled trial. J Indian Soc Periodontol 2011;15:398-401.

95. Waghmare PF, Chaudhari AU, Karhadkar VM, Jamkhande AS. Comparative evaluation of turmeric and chlorhexidine gluconate mouthwash in prevention of plaque formation and gingivitis: A clinical and microbiological study. J Contemp Dent Pract 2011;12:221-4.

96. Anupama D, Anil M. Surangama: A clinical trial to evaluate the effect of triphala as a mouthwash in comparison with chlorhexidine in chronic generalized periodontitis patient. Indian J Dent Adv 2010;2:243-7.

97. Al-Taee KT, Al-Ani SS, Al-Dulaimi KK, Al-Dulaimi MM. Antibacterial activity of crude herbal mixture (oak bark, Miswak, cinnamon, mint, clove, common camomile and glycerin oil) on oral pathogenic bacteria. Anbar Med J 2012;10:78-85.

98. Atul AP, Rajendra DP, Upendra CG, Sadanand YP, Aditya S, Arvind KP, et al. Antimicrobial activity of a poly-herbal extract against dental micro flora. Res J Pharm Biol Chem Sci 2011;2:533. 